\title{
Article \\ Open Innovation Strategies for Sustainable Urban Living
}

\section{Eva van Genuchten, Alicia Calderón González and Ingrid Mulder * (i)}

Faculty of Industrial Design Engineering, Delft University of Technology, 2628 CE Delft, The Netherlands; E.J.S.vanGenuchten@tudelft.nl (E.v.G.); A.CalderonGonzalez@tudelft.nl (A.C.G.)

* Correspondence: i.j.mulder@tudelft.nl; Tel.: +31-(0)15-278-5637

Received: 31 March 2019; Accepted: 11 June 2019; Published: 15 June 2019

check for updates

\begin{abstract}
Cities are increasingly seen as having an important role in tackling societal challenges related to climate change, while open innovation is increasingly accepted as a new way of working for governments. In the current work, we explore the role of open innovation to tackle global challenges on a city level. In the context of the city of Rotterdam and its vision on sustainability and liveability, seven collaborative initiatives are introduced. These initiatives aim to address both sustainability and liveability goals. Our research shows that in order to have these initiatives contribute to the overall municipal goal on sustainability and liveability, the municipality needs to take different roles. Whereas traditional open innovation literature usually distinguishes three main types of open innovation, namely outside-in, inside-out, and coupled processes, the current study shows that open innovation for sustainability in the city needs a much more fine-grained and elaborate perspective; a multi-level open innovation model that allows for different co-creative partnerships joining forces in sustainability challenges. It can be concluded that governments have a key role in infrastructuring these co-creative partnerships.
\end{abstract}

Keywords: cities; co-creative partnerships; infrastructuring; open innovation; public sector; sustainable urban living

\section{Introduction}

Today's social, economic, and environmental global challenges ask for radically different ways of working in order to transition towards a more sustainable society. The current systems that our society has been built on are increasingly under pressure. Differently put, we can no longer rely only on optimizing these systems and instead we need to be searching for radical alternatives [1]. So far, governments seem unable to cope with these challenges and are looking for new ways for innovation [2]. The fact that public sector organizations are oftentimes 'silo'-structured and generally defined by top-down, closed, hierarchical processes negatively affects the innovative possibilities within and beyond the boundaries of the organization [2]. Therefore, governments are increasingly looking for different governance mechanisms that open up this process by including interaction with citizens [3]. Almirall and colleagues [4] even state that the public sector has already largely adopted open innovation processes, mainly on the city level.

In the current work, we elaborate upon open innovation in urban contexts, with a focus on sustainability. Hence, cities put a great pressure on the world's energy and material resources, and in this way, cities negatively influence its sustainability [5]. Moreover, cities are vulnerable for climate disasters and environmental risks, such as floods and strong weather, since they are oftentimes located close to riverbanks or coasts due to economic reasons [6]. To become more sustainable, cities need to adapt to possible climate changes and work towards creating desirable futures [7]. Addressing sustainability in the city level requires an understanding of complex systems and the way they develop; 
to achieve it, an integrated approach is needed where, for instance, social and political systems are also taken into account [8]. Fortunately, cities also offer many opportunities for innovation [5,9] and consequently, cities can be referred to as "places where creative problem-solving flourishes" [9]. Cities are identified to a greater extent as "strategic arenas for climate change action", not only in the 2015 Paris Agreement for Climate Action, but also by several mayors of large cities like Paris, Rome, and New York [10]. By successfully addressing these issues on a local scale, cities can have impact on a global scale by inspiring other projects elsewhere [5]. This requires an ongoing conversation between the different actors, disciplines, and cultures that are working in that same area [9] and, therefore, a participatory way of working is needed to combine both bottom-up and top-down innovation processes through creating co-creative partnerships [1]. In the next section, we dive deeper in the concept of open innovation to scope its relevance in the public realm.

\section{The Concept of Open Innovation}

Open innovation finds its origin in the corporate context. Consequently, most literature on open innovation describes the concept from a business context. The shift towards open innovation can be defined as accelerating an organization's internal innovation processes by purposively using external knowledge and the outflow of internal knowledge [11]. In keeping with Chesbrough, an open innovation business model creates value from both internal and external ideas and creates internal mechanisms to claim a portion of that value [11]. Without going in too much detail, three types of open innovation can be distinguished: (1) outside-in, (2) inside-out, and (3) coupled processes [3]. With the first type, resources outside the firm are incorporated inside the organization. Doing inside-out innovation means to put resources from within the firm outside its own boundaries. In the third process, the first two are combined by working with partners and stakeholders that are complementary to each other [3]. Obviously, open innovation in the private and in the public sector is different in many ways. While open innovation in the private sector usually has new product development as a main goal, open innovation in the public sector generally focuses on improving service performance and creating public value [3]. Other motives that drive open innovation in the public sector are to reduce expenses, to let citizens participate in decision-making processes, or to advance economic circumstances for civilians [4]. Furthermore, open innovation is not often defined as a nationwide strategy, although most countries are experimenting with the concept in creating a separate unit or department for it [3].

Even though open innovation strategies have emerged in corporates, open innovation is also increasingly referred to in literature as a new way of governance to tackle sustainability challenges (e.g., [2-4,12,13]). We, therefore, elaborate upon the three different types of open innovation mentioned before and discuss how these can also be better framed in the public sector context. Exemplary outside-in open innovation strategies for the public sector can be found in the concept of citizen sourcing [13], which is defined as "the act of taking a task that is traditionally performed by a designated public agent (usually a civil servant) and outsourcing it to an undefined, generally large group of people in the form of an 'open call'." Hilgers and Ihl [12] distinguish three levels of open innovation in the public sector. As a first tier, 'citizen ideation and innovation' has been introduced, where citizens are involved through ideation and innovation challenges through online platforms to utilize the creativity and knowledge of the crowd. The second tier is referred to as 'collaborative administration', which means that common administrative tasks are improved through involving external actors in a systematic way. The third and final tier is entitled 'collaborative democracy', where larger groups of people are involved in policy making and implementation processes.

Other examples of open innovation in the public sector that next to outside-in also address inside-out open innovation strategies can be found in the literature on collaborative innovation [2]. Here, collaborative innovation refers to an opened-up innovation process, where "actors from within the organization, other organizations, the private and third sector, and citizens are integrated into the innovation cycle (idea generation, selection, implementation, and diffusion) from the earliest 
stage onwards" [2]. At the basis of this strategy is the assumption that actively involving different types of stakeholders with both tangible and intangible assets "will increase the quantity and quality of innovations". In addition, Lee, Hwang and Choi [3] describe a similar concept, citizen-centered governance, where a collaborative network of citizen experts is harnessed by the government to deal with problems more rapidly and precisely. They highlight that these networks can be both government-led and community-led.

Thirdly, examples of coupled processes can be found where it is not straightforward inside-out of outside-in, but where stakeholders are complementary to each other. Urban Living Labs (ULLs) elaborate upon open innovation at the urban scale, while deliberately including the civil society in co-creation processes. Differently put, ULLs [13] can be seen as a coupled process and have the aim to experiment and collaborate within an "open innovation ecosystem" between different stakeholders in a specific socio-spatial context. ULLs can be initiated bottom-up or top-down and are aiming to co-create with governmental stakeholders, educational institutions, corporates, and citizens (the quadruple helix) [13]. In an elaborate study, Puerari and colleagues [13] distinguish different levels of stakeholder involvement in co-creation processes: a core group, the inner circle, and the outer circle. The first level has the most intense co-creation, the most frequent interaction and has a formalized form of cooperation. The next group is actively involved in co-creation, has regular communication and a mix of formal and informal collaboration. The outer circle only passively co-creates, has sporadic interactions and the collaboration is more spontaneous. A ULL can be targeting one of the groups more or less for collaboration and co-creation. ULLs can be valuable for both municipalities, to expand their capacities, as well for active citizens, who can better express their voice in urban innovation and decision making processes. In similar vein, Almirall and his colleagues [4] propose an integrated eco-systems approach to manage external sources of innovation, in which both the competitive market and collaborative community are addressed. The competitive market has more formal relationships, is more profit-oriented and there is less sharing between stakeholders in the process. The collaborative community, on the other hand, shows more casual relations, more sharing among parties and a broader range of (intrinsic and extrinsic) motivations [4]. In this way, different stakeholders with their own motivations and skills can be accounted for better. Almirall and colleagues [4] distinguish six types of open innovation used simultaneously in different city governments: (1) open data, (2) hackathons and application development contests, (3) crowdsourcing, (4) embedded change agents, (5) urban labs, and (6) civic accelerators. Some of these types are overlapping with earlier described concepts of open innovation and are more typical inside-out or outside-in innovation, while other types such as urban labs and civic accelerators show a more coupled process. Almirall et al. [4] seem to have the business context as their reference, since they explain what businesses can learn from civic open innovation. Consequently, their contribution remains on product level and stresses the value of technological innovations and does not elaborate on the value of open innovation to drive societal and/or political change and how open innovation can contribute to the development of sustainable cities.

To summarize, many authors have proposed open innovation strategies for the public sector, and these strategies are being used on different levels of government. While some strategies focus on a national level and aim to include as much participants as possible, other strategies focus on a local level, stressing the diversity and quality of urban stakeholders. Moreover, a difference between the proposed strategies can be found in the type of interactions, ranging from digital interactions between government and citizens (citizensourcing) to using intermediaries (partly in integrated eco-systems approach) or face-to-face interactions in co-creative sessions (hackathons or ULLs). Lastly, the quality of the exchange of resources differs as well. In some initiatives, there is one leading party (usually the government) collecting multiple resources (e.g., ideas, time, knowledge) as a way to improve their own public services, while in other initiatives the input from the different participants is more equal. To tackle wicked problems such as creating sustainable cities, not only technological innovation is needed, but also a societal change, in which open innovation can be a helpful strategy as all levels of society can be involved in the innovation process. In general, the value of open innovation is 
usually explained from the perspective of the company or organization that is initiating the open innovation and that aims to improve its own products or services by inviting other companies, citizens or public sector in their innovation process. However, in the current work, we stress the inclusion of the civil society as the main objective is to innovate society as a whole. We, therefore, elaborate on open innovation strategies for sustainable urban living that address these societal challenges. We conclude that coupled processes are most valuable in transitioning towards more sustainable cities; it requires a variety of partners that are complementary to each other and are (more) equally contributing to and participating in these elaborate processes. However, we also envisage that a more fine-grained understanding is needed to define open innovation strategies for the public sector that can be used to tackle wicked societal problems, like strengthening a city's approach towards sustainability.

The main aim of the current work is to gain a more fine-grained understanding of open innovation strategies that can be valuable for transitioning towards sustainable urban living and elaborate upon the role of the public sector, while including the civil society.

In the remainder, we move from theory to practice and explore what open innovation strategies are used on a city level that contribute to sustainability in the city. The city of Rotterdam, well-known for its rich variety in actions towards sustainability has been chosen as context of study. The next section describes the method and further details on the research context; the city of Rotterdam and its vision on sustainability issues. This vision is illustrated through seven exemplary initiatives. These initiatives highlight urban innovation with an ambition of tackling societal issues related to sustainability, think $\mathrm{CO}_{2}$ emissions reduction, air quality or flood management. The results show a variety of challenges these examples are tackling as well as the different formations of stakeholders that took place in these examples. In the discussion, open innovation strategies are described, which the municipality of Rotterdam can use in opening up these innovation niches to other stakeholders in their innovation processes, while aiming for societal impact and to become a more sustainable city.

\section{Research Context and Method}

\subsection{Sustainable Urban Living as a City Vision}

As mentioned earlier, the city of Rotterdam has been chosen as context to analyze and identify different initiatives that aim at improving the city's sustainability. In the last decade, the municipality of Rotterdam has developed a strong vision and overall plan on the city's approach to sustainability. The first plans aimed at reducing $\mathrm{CO}_{2}$ emissions by $50 \%$ in 2025 [5]; this was followed by the founding of the Rotterdam Climate Initiative that introduced climate resilience on the city's agenda $[14,15]$.

Rotterdam is an interesting context to observe, not only as a city that that has set ambitious sustainability goals, but also as a metropolis that is dealing with urban challenges related to liveability. With a past marked by an erased city center in the German bombings of the Second World War, and a modern tradition of investing in big-scale urban developments, such as office skyscrapers and entertainment venues, the center of the city did not host many quality "third spaces" for its residents and tourists [15]. However, the local government has taken important actions to improve the quality of these spaces in the city, more interestingly, linking their long-term sustainability and liveability goals in actions such as the "inner city as city lounge" policy program [14,15]. These types of strategic and institutional actions have been materialized on the operational level in different urban interventions that, on the one hand, aim at tackling sustainability issues specific to the city of Rotterdam and, on the other hand, aim at improving the liveability in the city's public spaces [15]. In the remainder, we therefore refer to 'Sustainable Urban Living'. These actions making the city vision tangible are in keeping with what Concilio and Tosoni [9] refer to as the "institutional capacity" of a city. More specifically, this is one of five dimensions these authors discuss as contributing factors to the city's ability to be innovative; in this case, the strategic, institutional, and operational actions are an evidence of the Rotterdam government's "institutional and business ability to capture and align 
innovation 'niches' that might be relevant for systemic change (Geels, 2011; Puerari, Concilio, Longo \& Rizzo, 2013)" [9].

\subsection{Method}

The objective of this study is to explore innovation niches that translate the governmental vision of Sustainable Urban Living to an operational level. For this purpose, a small sample of different initiatives has been selected, to study new types of collaborations in order to inform the development of open innovation strategies for the municipality of Rotterdam. We refer to the quadruple-helix knowledge production model to provide insights into the dynamics of stakeholder relationships in these initiatives.

Seven urban initiatives have been selected based upon their relation with the implementation of the Rotterdam's municipality approach towards Sustainable Urban Living. The selected initiatives have in common that they are examples of innovative answers to address both the challenge of climate change and liveability in the city of Rotterdam; more specifically, they deal with flooding management, reduction of $\mathrm{CO}_{2}$ emissions or improving air quality while aiming for improving the quality of the city' spaces. Secondly, the Municipality of Rotterdam is involved somehow in all initiatives. Another important criterion of initiative selection has been the nature of the collaboration of different actors for innovation. We have selected initiatives on the premise of presenting both variety regarding stakeholders' formulation of the collaboration and quality in the exchange of the resources within the collaboration; knowledge, skills, and/ or tools brokerage in contrast to funding alone.

In the next section, the examples are described. In the results section, the examples are mapped in two different tables. The first one explains their relation to urban sustainable living. Secondly, types of stakeholders involved in each initiative are mapped, as well as their roles in the different initiatives, in order to primarily elaborate upon the different roles the municipality of Rotterdam takes in each of the examples.

\section{Initiatives Aiming for Sustainability and/or Liveability in Rotterdam}

Although part of a larger study, the examples presented have been explored through desk research using online resources (newspapers, initiatives' webpages, etc.) and, when available, literature describing the initiatives has been included. The descriptions contain the main challenge the initiative is focusing on, the motivation behind their innovation, the results that have been achieved, the person or group who has initiated, it and the collaborations that took place in the process; all these in order to analyze the open innovation strategies that the municipality of Rotterdam may be partaking. Figure 1 shows an overview of the initiatives.

\subsection{Blijstroom: Cooperative for Shared Solar Panel Energy}

Blijstroom is an energy collective or association, initiated by several citizens from diverse backgrounds, located in the North of Rotterdam, for which unused roofs are 'donated' to the neighborhood [16]. Citizens then collectively buy solar panels for this roof, from which they will receive part of the yield. The motivation to do this is that citizens wanted to create sources of clean energy for themselves and by themselves in Rotterdam North [17]. Moreover, they do not want to wait for the government to act, but they initiate renewable energy sources themselves [18]. Currently, they have completed two roofs and are developing a third one in different neighborhoods in Rotterdam. Furthermore, they visit different neighborhoods in Rotterdam to give free energy scans and give advice on the quick-fixes, like, for example, using weather strips. About 70 similar initiatives are present throughout the Netherlands. The platform of Qurrent is used to divide the profits of the generated energy (as a discount on the yearly energy bill) [19]. Moreover, the municipality of Rotterdam funded the Blijstroom initiative through CityLab010 [20]. The initiative operates on the neighborhood level and has face-to-face interactions with citizens, as well as digital interactions (through the Qurrent 
platform). The open innovation mainly takes place in the implementation stage, where the actual solar panel roofs are crowdfunded.

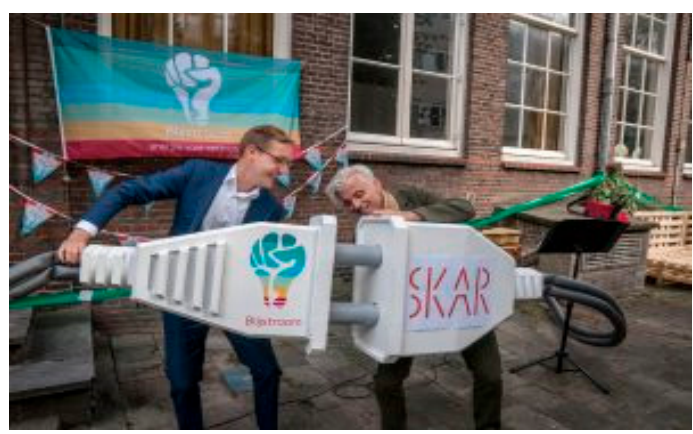

(a) Blijstroom

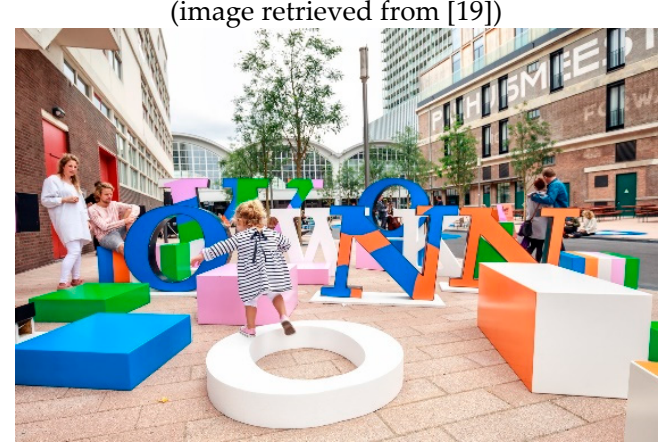

(c) Happy Streets

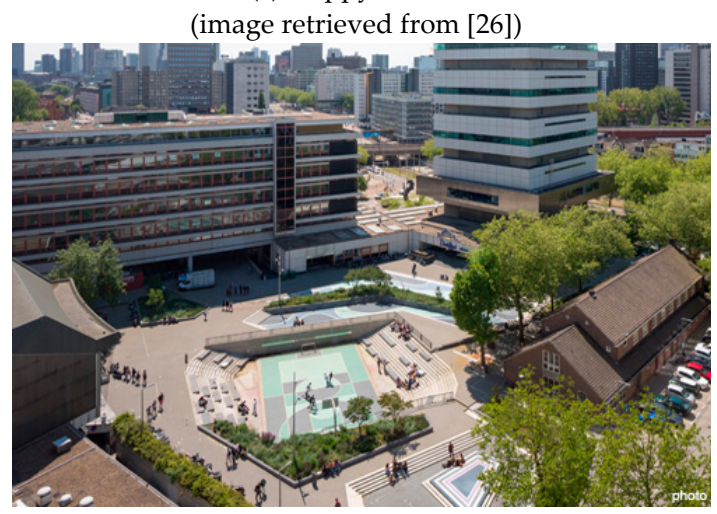

(e) Benthemplein Water Square

(image retrieved from [35])

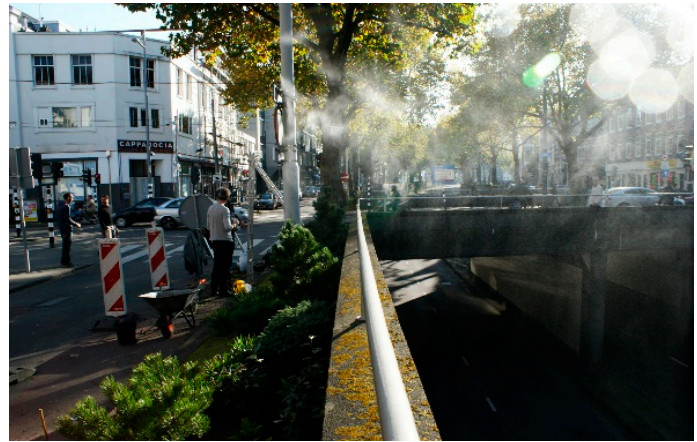

(b) ‘s Gravendijkwasstraat

(image retrieved from [24])

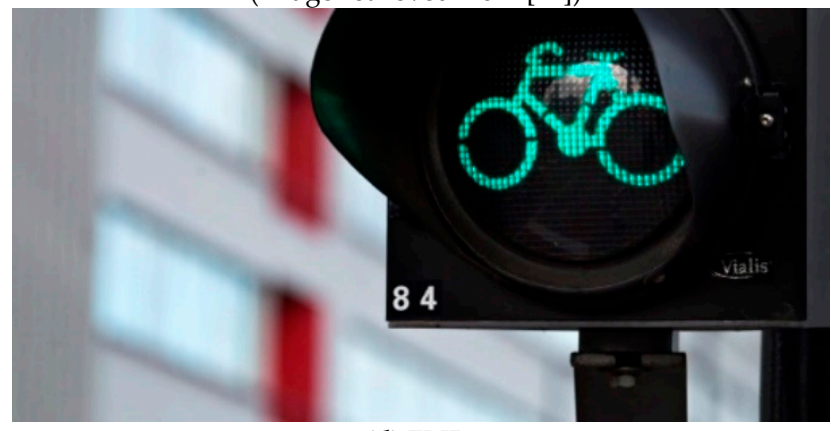

(d) FLIP

(image retrieved from [33])

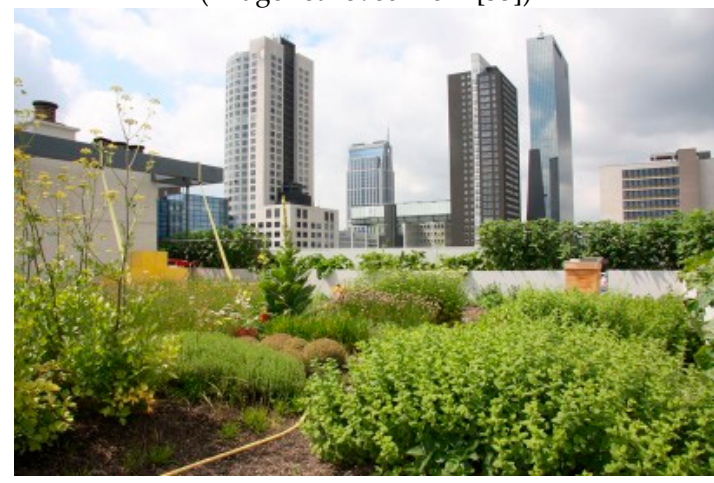

(f) Dakakker

(image retrieved from [43])

Ruimte voor water en groen

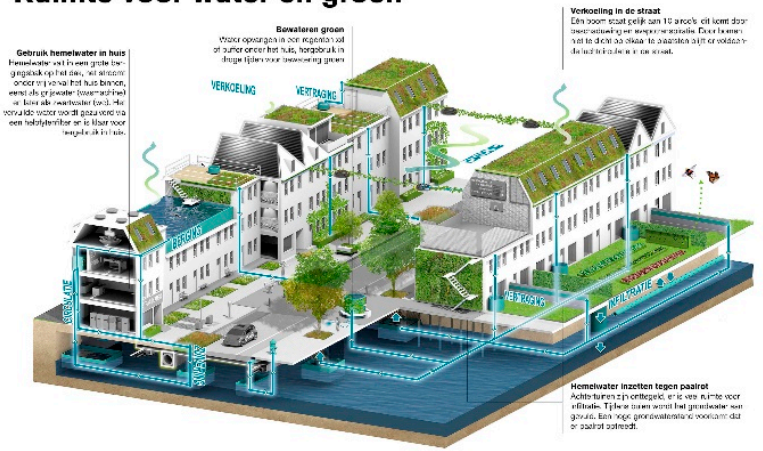

(g) StraaD (image retrieved from [44])

Figure 1. An overview of the seven initiatives. 


\section{2. 's Gravendijkwasstraat}

The 's Gravendijkwal is a street in Rotterdam, often used as a thoroughfare connecting the North and South of Rotterdam. Mainly due to the high traffic and congestions, the road has been one of the dirtiest streets in the Netherlands for years [21,22]. In 2015, the 'Stadslab Luchtkwaliteit' (which translates to Citylab for air quality and is initiated by a group of active citizens) started measuring the air quality in the street, in collaboration with the Dutch scientific organization 'Milieudefensie' (i.e., Environmental Defense) [23]. Both the European level for particulate matter and the standard set by the World Health Organization (WHO) are exceeded in this street. To make the air cleaner, the best and most sustainable solution is to have less and cleaner cars in the street [21,22]. However, that does not offer a solution on the short term, and the municipality initially didn't seem to be willing to do anything for the street [24]. Therefore, the organization Transformers [21] and Stadslab Luchtkwaliteit [23] developed an idea that provides a relief to the street in a more short-term solution: the so-called "s Gravendijk Wasstraat' (i.e., a car wash on the 's Gravendijkwal). This car wash consists of a series of thin pipes above the street that spray water into the air to create a fine mist. By doing this, the nitrogen dioxide $\left(\mathrm{NO}_{2}\right)$ precipitates, settles on the road surface and flows into the sewer. This is combined with moss and fine dust-catching vegetation on the sides of the road [21,22]. The technology is proven, but is used innovatively in the new context. In this project, many parties were working together, including the local residents and organizations for cleaner air. In the end, the idea was funded by the municipality through their platform Citylab010 [22]. The measurements of air quality will be continued until 2020 to show the impact of the intervention.

\subsection{Happy Streets}

Happy Streets is a Rotterdam-based organization that sets up temporary experiments in the streets of Rotterdam to create a more inclusive and sustainable mobility and to make better use of the public space. The experiments, organized together with the municipality, the residents, entrepreneurs, and researchers [25], are tactile interventions on the streets to test what type of solutions could work in the long term for the city of Rotterdam [26]. The interventions can be considered as prototypes of the vision of the municipality, as well with the short-term intention of attracting more citizens to spend their leisure time outside. An example of such an intervention is the Park(ing)day [27], where citizens, entrepreneurs, or artists can turn a parking space into a small park for one day. This is an internationally known movement and returning yearly in Rotterdam. A Happy Streets Index is also being developed by the group, which will be a research-based tool which can help policy makers to identify how spaces can be used best to increase happiness among people [28]. Happy Streets is a collaboration effort of the City of Rotterdam, the research institute DRIFT, and the urban agency Humankind and Street Events. It is an outcome of the "Mobility arena" (event facilitated by the municipality), as answer to the question how the participants of the session would imagine their city in 10 to 15 years and how they could contribute to that vision $[25,29]$. During the event, the collaboration agreed on three principles that would guide their future prototypes and interventions: "What is the end goal?", "What is the transition we want to accelerate?", and "Does it fit within the "Inner City as City Lounge' policy?" [30].

\subsection{FLIP: Traffic Light Interventions}

As part of a larger campaign to promote cycling behavior, the municipality of Rotterdam has implemented several interventions to experiment with ways to make the city friendlier towards bicycle traffic. The idea behind this is that cycling is healthy for the cyclist and improves the air quality of the city (sustainable mobility). For example, FLIP is a sort of traffic light that shows cyclists the shortest way to cross an intersection [31]. Another example is the heath sensor installed at the Churchill-plein. The heath sensor measures the number of cyclists waiting for a traffic light. When a huge group of cyclists is waiting at the traffic lights, cyclists get priority over motorized traffic. The test has to find a balance by creating a shorter waiting time for cyclists, and at the same time avoiding bigger 
congestions for cars [32]. If the experiments seem valid, they can be extended to other traffic lights and crossings in Rotterdam. According to the municipality of Rotterdam [33], input was collected from different sources to define the bicycle program, for example: district committees, stakeholders, and cyclists. A total of 435 comments were collected, mainly through the platform Fietsfan010 (which translates to Fan of Cycling Rotterdam). With this input, some changes were made to the original plan. For example, more attention was given to lighting on bicycle paths [33].

\subsection{Benthemplein Water Square}

This innovative square was an outcome of the collaboration of the urban and landscape design firm De Urbanisten, the Rotterdam Climate Initiative, and the City of Rotterdam, and supported by the Waterboard Schieland and Krimpenerwaard [34]. It has been built as an innovative answer to the city's problem of flood management. From the traditional approach of keeping the water out of the city, to using it as an aspect of the city liveability [35]; the Benthemplein is a specific example of this. The square is only one of the various water squares in the city that serve as deposits of water in moments of peak rainfall, lowering the demand for the city's sewage system and therefore preventing urban floods, to then gradually release the water collected [35]. When the Benthemplein square is dry, it offers the residents of the area a play area and other spaces to meet outdoors [34,36]. The water square was originally proposed by De Urbanisten and it sparked the interest of the municipality of Rotterdam, who decided to include it in their municipal water plan [37]. The development of the water square on Benthemplein, however, was not only a collaboration of the firm and the municipality. On a participation process led by the urban designers, neighbors and other residents that interact often with other facilities around the area, such as the school, church or gym, were encouraged to join three ideation workshops where their needs and the correspondent possible uses of the square were discussed $[34,35,38,39]$. The result is a square that is both a temporal water storage helping the city's resilience towards floods and a public space that improves the urban quality of the area [40].

\subsection{DakAkker: Rooftop Urban Farm}

The largest rooftop farm is situated in one of Rotterdam's city center office buildings [41]. The formerly abandoned building was repurposed into an innovative rooftop, where urban farm fruits, vegetables, herbs, and bee honey are harvested [41]. Moreover, it has a rooftop restaurant, where local produce can be eaten during breakfast or lunch [42]. On the roof, activities are organized, like workshops or harvest parties [42]. Depending largely on volunteers, the Dakakker combines multiple business models to sustain itself. Next to creating local food supplies, it also serves as water storage during peak rainfalls [14]. The initiative, which also works as a prototype and test site for experiments on urban farming and green rooftops, was started by ZUS Architects and developed in collaboration with the Rotterdams Milieucentrum (Environmental Centre Rotterdam) [42]. Other collaborators and funding partners are Stichting De Luchtsingel, Binder Groenprojecten, Rabobank Rotterdam, Stichting Bevordering van Volkskracht, Bureau Sustainable Rotterdam, and Nationale Postcodeloterij [42]. The DakAkker is part of a bigger concept to turn the Zomerhofkwartier (the neighborhood where the roof is located) into a climate-proof area [14].

\subsection{StraaD (Water-Sensitive Rotterdam)}

StraaD is a climate-conscious street proposal, where different forms of water storage in the public and private domain are combined with infiltration of waters into the ground throughout the street space by adding greenery. Green spaces in the street can act as a cooling system and purify the air, next to being a solution for floods control, and even for small scale food production by the local residents [43]. This initiative by the landscape architects Bosch Slabbers addresses different challenges related to climate change, such as floods and air pollution, as well as the decrease of public-space quality that streets have suffered in the last decades. The first test street is being developed in the city of Rotterdam, as a collaboration of the architects and the residents with different institutions, such 
as the local and regional governments of Rotterdam and Den Haag, NGOs such as Water Sensitive Rotterdam, companies and organizations, such as the knowledge institutes such as Deltares, and other parties of the street [44]. These different partners have contributed in the development of this proposal of the street of the future with knowledge, time, and/or money [43].

The ultimate ambition of the project is to create a change of mindset in society regarding our current design of streets, and adapt every street in urban areas of the Netherlands in order to make them smarter, climate resilient, and increase the quality of the public space for their residents; all that through designing the streets with the residents [45].

\section{Results}

For this research, different examples of initiatives with innovative proposals for city sustainability and/or liveability have been selected and studied. In this section, we include two tables that collect the outcomes of our analysis of the initiatives in regards to the urban challenge they address, that being improving the air quality or reduction of $\mathrm{CO}_{2}$ levels, flood management, and/or liveability (Table 1), as well as the collaboration that takes place in each instance (Table 2).

Table 1. The urban challenge(s) addressed by the initiatives.

\begin{tabular}{ccccc}
\hline & Air Quality & $\mathrm{CO}_{2}$ Reductions & Flood Management & Liveability \\
\hline Blijstroom & & $\mathrm{X}$ & & \\
's Gravendijk wasstraat & $\mathrm{X}$ & $\mathrm{X}$ & $\mathrm{X}$ \\
Happy streets & $\mathrm{X}$ & $\mathrm{X}$ & & $\mathrm{X}$ \\
FLIP & $\mathrm{X}$ & & $\mathrm{X}$ & $\mathrm{X}$ \\
Benthemplein water square & & $\mathrm{X}$ & $\mathrm{X}$ \\
DakAkker & $\mathrm{X}$ & $\mathrm{X}$ & $\mathrm{X}$ & $\mathrm{X}$ \\
StraaD & & & & \\
\hline
\end{tabular}

Table 2. The involved stakeholders in the initiatives, and their role in the specific example.

\begin{tabular}{|c|c|c|c|c|c|c|}
\hline & Municipality & Citizens & $\begin{array}{l}\text { Agency for Design } \\
\text { or Architecture }\end{array}$ & Industry & Academia & Other * \\
\hline Blijstroom & Funding & $\begin{array}{l}\text { Initiator + } \\
\text { Execution }\end{array}$ & & $\begin{array}{l}\text { Execution + } \\
\text { Knowledge }\end{array}$ & & \\
\hline $\begin{array}{l}\text { 's Gravendijk } \\
\text { wasstraat }\end{array}$ & Funding & $\begin{array}{c}\text { Initiator + } \\
\text { Knowledge } \\
+ \text { Execution }\end{array}$ & $\begin{array}{c}\text { Initiator + } \\
\text { Knowledge }+ \\
\text { Execution }\end{array}$ & & & $\begin{array}{l}\text { Knowledge } \\
+ \text { Execution }\end{array}$ \\
\hline Happy streets & $\begin{array}{l}\text { Initiator + } \\
\text { Funding }\end{array}$ & $\begin{array}{l}\text { Knowledge } \\
+ \text { Execution }\end{array}$ & $\begin{array}{c}\text { Initiator + } \\
\text { Knowledge + } \\
\text { Execution }\end{array}$ & & $\begin{array}{l}\text { Initiator + } \\
\text { Knowledge }\end{array}$ & \\
\hline FLIP & $\begin{array}{c}\text { Initiator + } \\
\text { Funding + } \\
\text { Knowledge } \\
+ \text { Execution }\end{array}$ & Knowledge & & & & Knowledge \\
\hline $\begin{array}{l}\text { Benthemplein } \\
\text { water square }\end{array}$ & $\begin{array}{l}\text { Initiator + } \\
\text { Funding }\end{array}$ & Knowledge & $\begin{array}{c}\text { Initiator + } \\
\text { Knowledge }\end{array}$ & Knowledge & & Funding \\
\hline DakAkker & Funding & Execution & $\begin{array}{c}\text { Initiator + } \\
\text { Knowledge }\end{array}$ & $\begin{array}{l}\text { Funding + } \\
\text { Knowledge }\end{array}$ & & $\begin{array}{l}\text { Knowledge } \\
+ \text { Execution } \\
+ \text { Funding }\end{array}$ \\
\hline StraaD & $\begin{array}{l}\text { Funding + } \\
\text { Knowledge }\end{array}$ & & $\begin{array}{c}\text { Initiator + } \\
\text { Knowledge + } \\
\text { Execution }\end{array}$ & $\begin{array}{l}\text { Knowledge } \\
+ \text { Execution }\end{array}$ & Knowledge & $\begin{array}{l}\text { Knowledge } \\
+ \text { Funding }\end{array}$ \\
\hline
\end{tabular}

To understand how these initiatives came to fruition, we have mapped what stakeholders or agents of the quadruple helix (government, citizens, academia, industry) are involved in each initiative. Moreover, their roles within the collaboration are described in the table: initiator of the project, provider of the funding, provider of (expert) knowledge, and/or execution of the project. Providing 
knowledge can be either some form of expert knowledge, or knowledge of citizens on their own living environment. The aim is to understand the possible different roles the municipality of Rotterdam takes in collaborations for open innovation for sustainability in the city.

\section{Discussion}

The selected innovative initiatives showed a dynamic variety in collaboration among the different urban stakeholders. Moreover, they showed different roles of the municipality in participating in open innovation in the city. However, it was not straightforward whether the type of open innovation at hand should be referred to as an outside-in, inside-out, or as a coupled process. Our data collection showed that multiple parties collaborated and contributed to the impact of the project, although, some initiatives were community-led while others were government-led, and in other cases the initiation of the project was the result of an initial collaboration, therefore there was not a defined single initiator. In the current section, we elaborate upon the observed collaboration among partners, as well as the availability of co-creation processes and the value or outcome of the collaboration. Although in all initiatives the municipality was involved, it was not always the municipality who was 'doing' the actual open innovation. However, the municipality was playing a crucial role in all selected initiatives. In the remainder of the discussion, we elaborate upon what ways local governments can open up their innovation processes to citizens and other urban stakeholders and what roles open innovation strategies should enable in order to activate a broader change and transformation process.

Through our exploration, we have identified three strategies of open innovation, depending on the role of the municipality in the collaboration and the impact of this collaboration on the different actors involved. Figure 2 shows the first strategy observed, which can be seen as a basic type of collaboration for open innovation; the municipality involves other agents, such as the city locals or an expert, in order to collect input that will be processed inside the local government. In these initiatives, the municipality applies an outside-in approach with the intention of learning from other agents. There is, therefore, no co-creation process or agreed common goal between the municipality and, for example, the citizens; the collection of input is driven by the goal of the initiating party. The initiatives that fit within this level are usually temporary experiments or small-scale urban interventions. Among those we explored, we observe this level of open innovation in example four, FLIP, the traffic light interventions for the improvement of cycling traffic in the city.

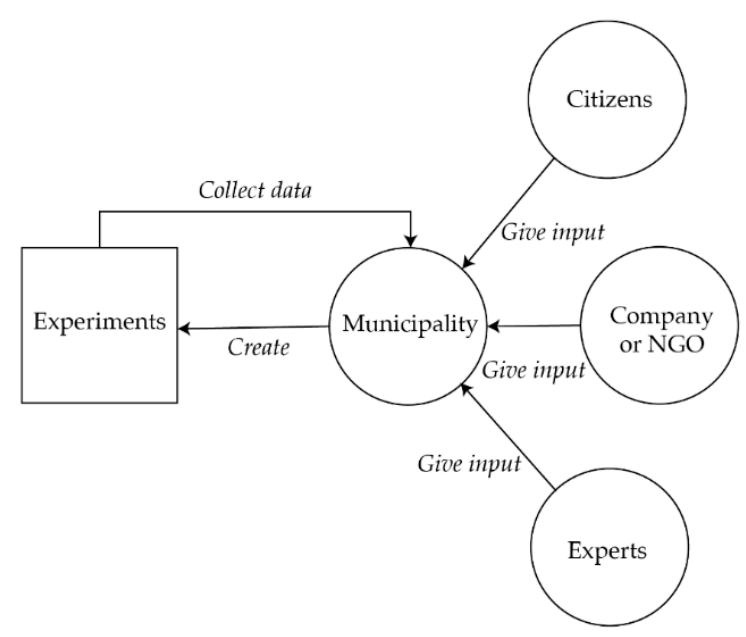

Figure 2. The first strategy of open innovation on a city level, the municipality as facilitator.

Figure 3 shows a second strategy identified, where the municipality is taking the role of the main funding agency and an infrastructuring agent of an open innovation process, without partaking of the learnings generated from these processes, or being involved in a co-creation process. Regarding the selected initiatives, we identified this practice in, for example, the initiatives of Blijstroom and 's 
Gravendijkwasstraat. Both initiatives received funding from the municipality's platform CityLab010, which is an experiment for democratic innovation and infrastructures bottom-up innovation. Through an authority such as Citylab010, the municipality of Rotterdam creates fertile grounds for the generation of a participatory climate and for innovative initiatives to flourish. In this way, Citylab010 distinguishes itself from other forms of 'citizensourcing'. Hence, the platform's main objective is not to collect multiple ideas from the citizens, but to experiment with how to facilitate and infrastructure a participation culture in the city. Moreover, next to funding, the platform also provides insights into the organizational structure of the municipality-for example, who to contact in regards to each topic-and provides the possibility for initiators to contact other urban stakeholders. Obviously, these open innovation practices show an infrastructuring role of the municipality in broadening open innovation for public value.

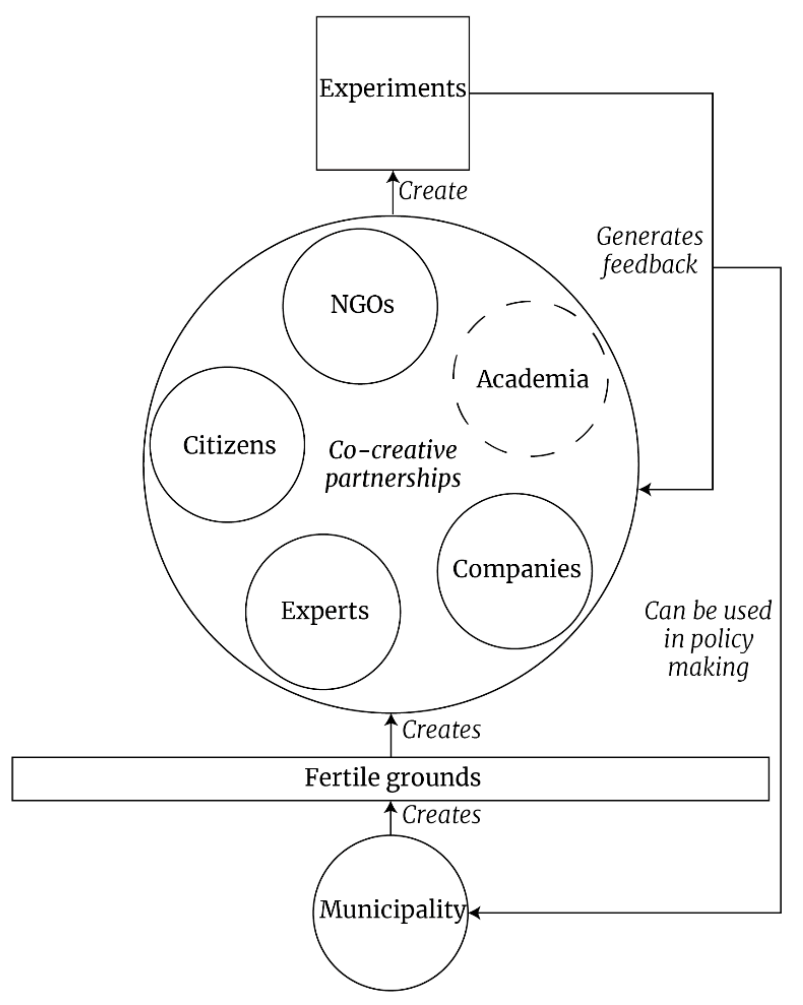

Figure 3. The second strategy of open innovation on a city level, the municipality as infrastructurer.

A third strategy for open innovation can be observed in those initiatives where all stakeholders were closely involved along the collaboration process and started to act in a co-creative partnership with other stakeholders [46]. Figure 4 shows this third strategy of open innovation, where open innovation is highly collective and co-creation plays an important role on multiple levels in the development process. While the different parties involved in these processes might also have individual intentions to join the collaborative process, they also all have a common goal in mind, to create societal change and to transition towards a more sustainable future. This changes the dynamics of an open innovation process, and enables knowledge brokerage across the partners involved, to fulfil this common goal. Exemplary initiatives illustrating this third strategy are initiative five, Benthemplein water square, and exemplary initiative seven, StraaD, where all stakeholders have an important and clear role towards the shared goal of transforming Dutch streets into climate resilient and liveable streets. They also openly share the generated knowledge; whereby interested parties can join or help in this transition.

While all parties gain knowledge from the process, the municipality has a clearer learning process. For example, Benthemplein square was implemented after a failed pilot on 'Bloemhofplein'. They learned from the initial pilot that the context in which the square is placed is crucial, and that citizen involvement is very important to implement it successfully [37]. These lessons learned are also 
taken further in the other similar squares that are developed in Rotterdam. Another striking aspect in the explored initiatives in the third strategy is that the municipality actively steers for a co-creative process with their citizens, but that there is usually an intermediary, like a design or architecture firm, taking care of the co-creative process.

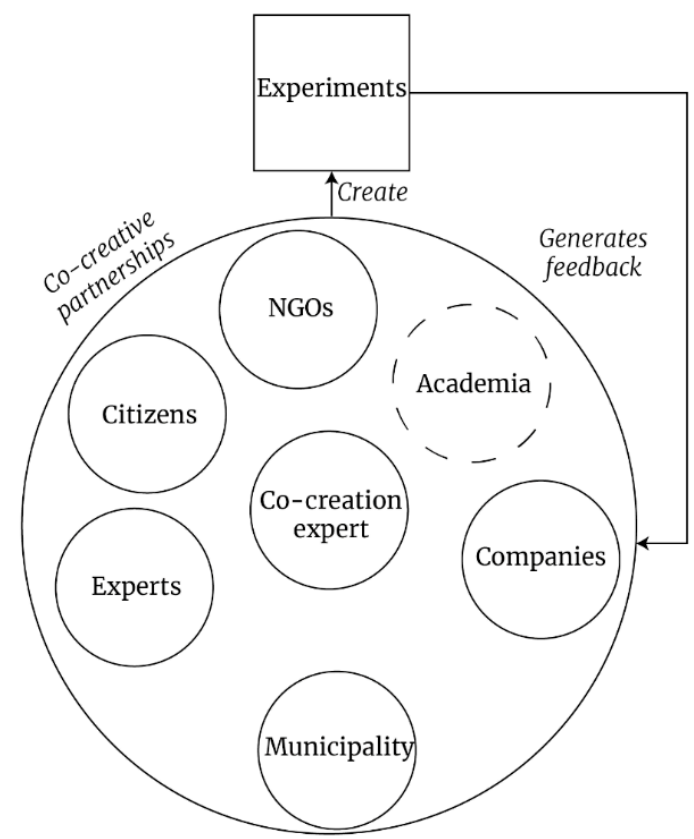

Figure 4. The third strategy of open innovation on a city level, the municipality taking part in co-creative partnerships.

\section{Conclusions, Limitations and Implications}

It can be concluded that the municipality of Rotterdam has been experimenting and changing their role across the various initiatives. Whereas the first strategy as facilitator of open innovation differs not so much from common strategies in a corporate context, hence, incumbent organizations invite (lead) users and other external stakeholders to join in for co-creation in their new product-service development process, the second and third strategy both highlight a wider and more complex reality. Moreover, the latter strategies do stress the role of cities as innovation hubs of heterogeneous networks, enabling collaboration across multiple levels. Differently put, the three open innovation strategies can be seen as stages of maturity for social innovation, see, for example, the social innovation spiral coined by the Young Foundation spiral [47]. The initiatives referred to in the first strategy can be identified as interventions in the inception stage of maturity $[47,48]$. The initiatives mentioned at the second strategy are infrastructured by the support and funding offered in Citylab010. The municipality initiated a platform to infrastructure various different small to medium initiatives and/or design-enabled urban interventions that ultimately contribute to an open innovation climate in the city. The final stages of the maturity spiral are in keeping with our third open innovation strategy, where the infrastructuring has turned temporary experiments into (semi)permanent innovations, and collaboration has been matured into co-creative partnerships, enabling long-term collaboration across multiple levels. On top of that, the third strategy stresses the knowledge brokerage, where all partners continue to learn from the co-creation process and continue to diffuse lessons to a broader society.

Whereas the main objective of the current study was to explore the potential of open innovation strategies for Sustainable Urban Living and the role of the municipality herein, we only introduced a limited set of initiatives to illustrate the open innovation strategies. Even though, we see this selection as representative for many other initiatives in the city, and as such, it can be concluded that the open 
innovation strategies have sparked not only a change in the local ecosystem and a widening of open innovation, but it also enables the city to move closer to sustainable development goals.

Using open innovation strategies in a city context can also have disadvantages, when not carefully executed. The government has a key role to ensure the embedment over time beyond temporary experiments, while taking into account the governance of public interest and public values. For example, interest groups can have hidden agendas and deliberately try to manipulate the decision-making process [2]. In a worst-case scenario, this would not create broader societal value, and leaves (economic) value for just one of the parties. Moreover, in an open innovation process, it is more difficult to distinguish who is responsible and accountable for the outcomes of the project [2]. Lastly, the different decision-making processes of the municipality and start-ups, for example, can create difficulties in operationalizing innovations [49].

A final remark on the city of Rotterdam as the context of research is that the city is already prone towards innovation in the urban context. For this reason, other cities could need different strategies for open innovation. Although the innovation niches are well embedded in the urban context, the current research has its limitations, as we only explored the institutional capacity in the context of the city's proneness towards open innovation. However, the main aim was to open the debate concerning how to study a city's innovation potential. It might be worthwhile to further elaborate how innovation niches could be studied and how open innovation strategies could infrastructure temporary experiments into a coherent innovative urban fabric.

Author Contributions: E.v.G. initiated the literature review on open innovation. E.v.G. and A.C.G. selected and described the innovation niches. E.v.G., A.C.G. and I.M. collaboratively wrote and revised manuscript.

Funding: The current work has been partly conducted within the context of the Participatory City Making project, which is granted in the research program Research through Design with project number 14604, Ingrid Mulder, Principal Investigator, and (partly) financed by the Netherlands Organization for Scientific Research (NWO) as well as in the context of DESIGNSCAPES-Building Capacity for Design enabled Innovation in Urban Environments, which is granted in the Horizon2020 COCREATION program with Grant Agreement Number 763784. The APC was funded by Delft University of Technology.

Conflicts of Interest: The authors declare no conflict of interest. The founding sponsors had no role in the design of the study; in the collection, analyses, or interpretation of data; in the writing of the manuscript, and in the decision to publish the results.

\section{References}

1. Mulder, I. Sociable smart cities: Rethinking our future through co-creative partnerships. In Distributed, Ambient, and Pervasive Interactions. DAPI 2014. Lecture Notes in Computer Science; Streitz, N., Markopoulos, P., Eds.; Springer: Cham, Switzerland, 2014; Volume 8530, ISBN 978-3-319-07788-8. [CrossRef]

2. Bommert, B. Collaborative innovation in the public sector. Int. Public Manag. Rev. 2010, 11, 15-33.

3. Lee, S.M.; Hwang, T.; Choi, D. Open innovation in the public sector of leading countries. Manag. Decis. 2012, 50, 147-162. [CrossRef]

4. Almirall, E.; Lee, M.; Majchrzak, A. Open innovation requires integrated competition-community ecosystems: Lessons learned from civic open innovation. Bus. Horiz. 2014, 57, 391-400. [CrossRef]

5. Roorda, C.; Frantzeskaki, N.; Loorbach, D.; Steenbergen, F.; van Wittmayer, J. Transition Management in Urban Context_Guidance Manual, Collaborative Evaluation Version; Drift, Erasmus University Rotterdam: Rotterdam, The Netherlands, 2012.

6. Rosenzweig, C.; Solecki, W.; Hammer, S.A.; Mehrotra, S. Cities lead the way in climate-change action. Nature 2010, 467, 909-911. [CrossRef] [PubMed]

7. Larsen, K.; Gunnarsson-Östling, U. Climate change scenarios and citizen-participation: Mitigation and adaptation perspectives in constructing sustainable futures. Habitat Int. 2009, 33, 260-266. [CrossRef]

8. Childers, D.L.; Cadenasso, M.L.; Grove, J.M.; Marshall, V.; McGrath, B.; Pickett, S.T.A. An Ecology for Cities: A Transformational Nexus of Design and Ecology to Advance Climate Change Resilience and Urban Sustainability. Sustainability 2015, 7, 3774-3791. [CrossRef]

9. Concilio, G.; Tosoni, I. Introduction. In Innovation Capacity and the City; Concilio, G., Tosoni, I., Eds.; Springer: Cham, Switzerland, 2019; pp. 1-14. ISBN 978-3-030-00123-0. [CrossRef] 
10. Castan Broto, V. Urban Governance and the Politics of Climate Change. World Dev. 2017, 93, 1-15. [CrossRef]

11. Chesbrough, H. Open innovation: A new paradigm for Understanding Industrial Innovation. In Open Innovation: Researching a New Paradigm, 1st ed.; Chebrough, H., Vanhaverbeke, W., West, J., Eds.; Oxford University Press: Oxford, UK, 2006; pp. 1-12. ISBN 0199290725.

12. Hilgers, D.; Ihl, C. Citizensourcing: Applying the Concept of Open Innovation to the Public Sector. Int. J. Public Particip. 2010, 4, 68-88.

13. Puerari, E.; de Koning, J.; von Wirth, T.; Karré, P.M.; Mulder, I.J.; Loorbach, D.A. Co-creation Dynamics in Urban Living Labs. Sustainability 2018, 10, 1893. [CrossRef]

14. Hölscher, K.; Frantzeskaki, N.; Loorbach, D. Steering transformations under climate change: Capacities for transformative climate governance and the case of Rotterdam, The Netherlands. Reg. Environ. Chang. 2018, 19, 791-805. [CrossRef]

15. Romein, A.; Trip, J.J. Key elements of creative city development: An assessment of local policies in Amsterdam and Rotterdam. In Proceedings of the City Futures ‘09, Madrid, Spain, 4-6 June 2009.

16. Krishnamurthy, S. Feasibility Study on Making Van Maanenblok a Near Zero Energy Building Urban Neighbourhood. Master's Thesis, KTH, Stockholm, Sweden, August 2014.

17. Nieuwe Business Modellen. Available online: http://nieuwebusinessmodellen.nl/map/thema/duurzaamheid /blijstroom/ (accessed on 15 March 2019).

18. Blijstroom. Available online: https://blijstroom.nl/ (accessed on 9 June 2019).

19. Qurrent. Available online: https://community.qurrent.nl/zonne-energie-en-zonnepanelen-4/blijstroom-3263 (accessed on 15 March 2019).

20. Blijstroom. Available online: https://citylab010.nl/initiatieven/archief/blijstroom (accessed on 15 March 2019).

21. Transformism. Available online: http://www.transformism.org/posts/view/55 (accessed on 4 December 2018).

22. 's Gravendijkwasstraat. Available online: https://www.citylab010.nl/plannen/sgravendijkwasstraat (accessed on 4 December 2018).

23. Stadslab Luchtkwaliteit. Available online: https://www.stadslabluchtkwaliteit.nl/ (accessed on 4 December 2018).

24. RTV Rijnmond. Available online: https://www.rijnmond.nl/nieuws/149916/Bewoners-s-Gravendijkwal-raz end-over-opknappen-Coolsingel (accessed on 4 December 2018).

25. Happy Streets. Available online: http://happystreets.nl/over/ (accessed on 6 December 2018).

26. Drift. Available online: https://drift.eur.nl/wp-content/uploads/2016/12/Nieuwe_wegen_inslaan_mobiliteits arenaRdam.pdf (accessed on 6 December 2018).

27. Parking Day. Available online: http://happystreets.nl/parking-day/ (accessed on 6 December 2018).

28. Dutch News. Available online: https://www.dutchnews.nl/features/2018/03/meet-happy-streets-rotterdamscheeky-activists-for-social-mobility-in-the-city/ (accessed on 10 December 2018).

29. Pattianakotta, J. Duurzame Mobiliteit Als Doel of Middel. Bachelor's Thesis, Radboud Universiteit Nijmegen, Nijmegen, The Netherlands, August 2017.

30. Bruntlett, M.; Bruntlett, C. Streets Aren't Set in Stone. In Building the Cycling City; Bruntlett, M., Bruntlett, C., Eds.; Island Press: Washington, DC, USA, 2018; pp. 7-26. ISBN 978-1-61091-880-0.

31. Gezondere Lucht. Available online: https://gezonderelucht.nl/actueel/flips-helpen-fietsers-sneller-overstek en (accessed on 10 December 2018).

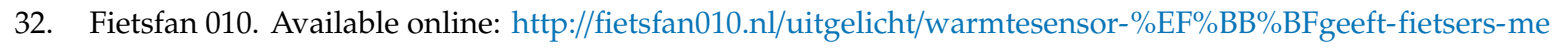
er-groen/ (accessed on 10 December 2018).

33. Fietsplan Rotterdam. Available online: https://www.rotterdam.nl/wonen-leven/fietsplan/ (accessed on 10 December 2018).

34. De Urbanisten (Waterplein Benthemplein). Available online: http://www.urbanisten.nl/wp/?portfolio=wate rplein-benthemplein (accessed on 15 March 2019).

35. Benthemplein Water Square: An Innovative Way to Prevent Urban Flooding in Rotterdam. Available online: https://www.c40.org/case_studies/benthemplein-water-square-an-innovative-way-to-prevent-ur ban-flooding-in-rotterdam (accessed on 15 March 2019).

36. Diaz, P.; Yeh, D. Adaptation to climate change for water utilities. In Water Reclamation and Sustainability; Elsevier: Amsterdam, The Netherlands, 2014; pp. 19-56. [CrossRef] 
37. Bressers, N. The impact of collaboration on innovative projects: A study of Dutch water management. In Public Innovation through Collaboration and Design, 1st ed.; Ansell, C., Torfing, J., Eds.; Routledge: London, UK, 2014; pp. 107-123, ISBN 9781134452859.

38. Bressers, N.; Edelenbos, J. Planning for adaptivity: Facing complexity in innovative urban water squares. Emerg. Complex. Organ. 2014, 16, 77-99. Available online: https://search.proquest.com/docview/1681098795 ?accountid=27026 (accessed on 15 March 2019).

39. Errigo, M. The Adapting city. Resilience through water design in Rotterdam. TeMa-J. Land Use Mobil. Environ. 2018, 11, 51-64. [CrossRef]

40. De Urbanisten (Climate Proof Zomerhofkwartier). Available online: http://www.urbanisten.nl/wp/?portfoli o=climate-proof-zomerhofkwartier (accessed on 15 March 2019).

41. Resilient Rotterdam. Available online: https://www.resilientrotterdam.nl/en/initiatieven/green-roof-harvest s-1 (accessed on 15 March 2019).

42. De Luchtsingel. Available online: https://www.luchtsingel.org/en/locaties/roofgarden/ (accessed on 15 March 2019).

43. De straaD. Available online: http://www.destraad.nl (accessed on 15 March 2019).

44. Water Sensitive Rotterdam. Available online: https://www.watersensitiverotterdam.nl/plekken/de-straad/ (accessed on 15 March 2019).

45. Bosch Schlabbers. Available online: https://www.boschslabbers.nl/nl/project/straad/ (accessed on 15 March 2019).

46. Mulder, I. Co-creative partnerships as catalysts for social change. Strateg. Des. Res. J. 2018, 11, 178-185. [CrossRef]

47. Murray, R.; Calulier-Grice, J.; Geoff, M. The Open Book of Social Innovation; The Young Foundation: London, UK, 2010; ISBN 987-1-84875-071-5.

48. Mulder, I.; Kun, P. Hacking, Making, and Prototyping for Social Change. In The Hackable City; de Lange, M., de Waal, M., Eds.; Springer: Singapore, 2019; pp. 225-238. ISBN 978-981-13-2694-3. [CrossRef]

49. Ojasalo, J.; Tähtinen, L. Integrating open innovation platforms in public sector decision making: Empirical results from smart city research. Technol. Innov. Manag. Rev. 2016, 6, 38-48. Available online: http: //timreview.ca/article/1040 (accessed on 15 March 2019).

(C) 2019 by the authors. Licensee MDPI, Basel, Switzerland. This article is an open access article distributed under the terms and conditions of the Creative Commons Attribution (CC BY) license (http://creativecommons.org/licenses/by/4.0/). 